Article

\title{
Secondary Metabolites with Nitric Oxide Inhibition from Marine-Derived Fungus Alternaria sp. 5102
}

\author{
Senhua Chen ${ }^{2,3,+} \oplus$, Yanlian Deng ${ }^{1,+}$, Chong Yan ${ }^{1}$, Zhenger $\mathrm{Wu}^{2}$, Heng Guo ${ }^{2}$, Lan Liu ${ }^{2,3}(\mathbb{D}$ and \\ Hongju Liu ${ }^{1, *}$ \\ 1 School of Pharmacy, Guangdong Medical University, Dongguan 523808, China; \\ dengylian2016@163.com (Y.D.); jdsbj2000@163.com (C.Y.) \\ 2 School of Marine Sciences, Sun Yat-sen University, Guangzhou 510006, China; \\ chensenh@mail.sysu.edu.cn (S.C.); wuzher@mail2.sysu.edu.cn (Z.W.); hengeguo163@163.com (H.G.); \\ cesllan@mail.sysu.edu.cn (L.L.) \\ 3 Southern Laboratory of Ocean Science and Engineering (Guangdong, Zhuhai), Zhuhai 519000, China \\ * Correspondence: liuhj8@mail2.sysu.edu.cn; Tel.: +86-769-22896599 \\ + These authors contributed equally to this work.
}

Received: 25 July 2020; Accepted: 10 August 2020; Published: 14 August 2020

\begin{abstract}
Two new benzofurans, alternabenzofurans A and B (1 and 2) and two new sesquiterpenoids, alternaterpenoids A and B (3 and 4), along with 18 known polyketides (5-22), were isolated from the marine-derived fungus Alternaria sp. 5102. Their structures were elucidated on the basis of extensive spectroscopic analyses (1D and 2D NMR, HR-ESIMS, and ECD) and X-ray crystallography, as well as the modified Mosher's method. Compounds 2, 3, 5, 7, 9-18, and 20-22 exhibited potent anti-inflammatory activity by inhibiting the production of NO in RAW264.7 cells activated by lipopolysaccharide with $\mathrm{IC}_{50}$ values in the range from 1.3 to $41.1 \mu \mathrm{M}$. Structure-activity relationships of the secondary metabolites were discussed.
\end{abstract}

Keywords: marine-derived fungus; secondary metabolites; Alternaria; anti-inflammatory

\section{Introduction}

Marine-derived fungi are a significant source of pharmacological molecules with interesting and diversified structural properties [1-4]. Among them, the fungal genus Alternaria had a widespread distribution in marine source [4] (including sediment [5], sponge [6], alga [7], mangrove [8], soft coral [9]) and could produce plenty of structural molecules, including nitrogen-containing compounds, steroids, terpenoids, pyranones, quinones, and phenolics [10]. These metabolites exhibited a variety of biological activities such as cytotoxic, antimicrobial, enzyme inhibitor properties [10]. For instances, naphtho- $\gamma$-pyrones pyrophen displayed anti-fungal activity against $C$. albicans from the marine-derived fungus Alternaria alternate D2006 [11], anthraquinone anthrininone A showed significant inhibition activity against indoleamine 2,3-dioxygenase 1 (IDO1) from the deep-sea derived fungus Alternaria tenuissima DFFSCS013 [12], drimane meroterpenoid alternarin A revealed effective inhibition of spontaneous synchronous $\mathrm{Ca}^{2+}$ oscillations from the coral-associated fungi Alternaria sp. ZH-15 [13].

Recently, we searched for anti-inflammatory secondary metabolites from the South China Sea [14-17]. EtOAc extract of marine-derived fungus Alternaria sp. 5102 showed anti-inflammatory activity in vitro by inhibiting nitric oxide (NO) production in lipopolysaccharide activated in RAW264.7 cells. Subsequent chemical investigation led to the isolation of 22 secondary metabolites, including two new benzofurans, alternabenzofurans A and B (1 and 2) and two new sesquiterpenoids, alternaterpenoids A and B (3 and 4), 
along with 18 known polyketides, isobenzofuranone A (5) isoochracinic acid (6), (R)-1,6-dihydroxy-8-methoxy-3a-methyl-3,3a-dihydrocyclopenta[c]isochromene-2,5-dione dihydroaltenuenes A (8), phialophriol (9), \pm talaroflavone (10), alternariol-9-O-methyl ether (11), alternariol (12), 2-methyl-9-methoxy alternariol (13), 3'-hydroxyalternariol 5-O-methyl ether (14), alternariol-1'-hydroxy-9-methyl ether (15), dehydroaltenusin (16), alteryulactone (17), tenuissimasatin (18), 5'-methoxy-6-methyl- biphenyl-3,4,3'-triol (19), altenusin (20), 2,5-dimethyl-7-hydroxychromone (21) and walterolactone $C$ (22) (Figure 1). Their structures were identified by extensive spectroscopic analyses (1D and 2D NMR, HR-ESIMS, and ECD) and X-ray crystallography, as well as the modified Mosher's method. Compounds 2, 3, 5, 7, 9-18, and 20-22 showed potential anti-inflammatory activity with $\mathrm{IC}_{50}$ values ranging from 1.3 to $41.1 \mu \mathrm{M}$. Herein, we report the isolation, structure determination, and anti-inflammatory bioactivity of the secondary metabolites.<smiles>C[C@@H](OC(=O)C[C@@H]1OC(=O)c2c(O)cccc21)[C@@H](O)I</smiles>

1<smiles>[R]C(=O)CC1OC(=O)c2c(O)cccc21</smiles>

$5 \mathrm{R}=\mathrm{OCH} 3$ $6 \mathrm{R}=\mathrm{H}$<smiles>COc1cc(O)c2c(c1)C1(OC2=O)C(C)=CC(=O)C1O</smiles>

10<smiles>[R]c1cc(O)c2c(=O)oc3c([R3])c([R4])c([R])c([R])c3c2c1</smiles><smiles>COc1cc(O)cc(-c2cc(O)c(O)cc2C)c1</smiles>

19<smiles>C[C@H](O)[C@@H](C)OC(=O)C[C@H]1OC(=O)c2c(O)cccc21</smiles>

2<smiles>COc1cc(O)c2c(c1)C1=C(O)C(=O)C[C@@]1(C)OC2=O</smiles>

7<smiles>COc1cc(O)c2c(c1)C1=CC(=O)C(O)=C[C@@]1(C)OC2=O</smiles>

16<smiles>COc1cc(O)c2c(c1)-c1cc(O)c(O)cc1COC2=O</smiles>

17<smiles>COC(=O)C1Cc2cccc(O)c2C(=O)O1</smiles>

18

$$
\begin{aligned}
& 11 \mathrm{R}_{1}=\mathrm{OCH}_{3}, \mathrm{R}_{2}=\mathrm{CH}_{3}, \mathrm{R}_{3}=\mathrm{H}, \mathrm{R}_{4}=\mathrm{OH}, \mathrm{R}_{5}=\mathrm{H} \\
& 12 \mathrm{R}_{1}=\mathrm{OH}, \mathrm{R}_{2}=\mathrm{CH}_{3}, \mathrm{R}_{3}=\mathrm{H}, \mathrm{R}_{4}=\mathrm{OH}, \mathrm{R}_{5}=\mathrm{H} \\
& 13 \mathrm{R}_{1}=\mathrm{OCH}_{3}, \mathrm{R}_{2}=\mathrm{H}, \mathrm{R}_{3}=\mathrm{CH}_{3}, \mathrm{R}_{4}=\mathrm{OH}, \mathrm{R}_{5}=\mathrm{H} \\
& 14 \mathrm{R}_{1}=\mathrm{OCH}_{3}, \mathrm{R}_{2}=\mathrm{CH}_{3}, \mathrm{R}_{3}=\mathrm{H}, \mathrm{R}_{4}=\mathrm{R}_{5}=\mathrm{OH} \\
& 15 \mathrm{R}_{1}=\mathrm{OCH}_{3}, \mathrm{R}_{2}=\mathrm{OH}, \mathrm{R}_{3}=\mathrm{H}, \mathrm{R}_{4}=\mathrm{CH}_{2} \mathrm{OH}, \mathrm{R}_{5}=\mathrm{H}
\end{aligned}
$$<smiles>COc1cc(O)c(C(=O)O)c(-c2cc(O)c(O)cc2O)c1</smiles><smiles>Cc1cc(=O)c2c(C)cc(O)cc2o1</smiles>

21<smiles>C[C@@H]1CC(=O)OC[C@H]1O</smiles>

22

Figure 1. Chemical structures of 1-22. 


\section{Results and Discussion}

Alternabenzofuran A (1) was obtained as a colorless crystal. The molecular formula of $\mathbf{1}$ was established as $\mathrm{C}_{14} \mathrm{H}_{16} \mathrm{O}_{6}$ based on the HR-ESIMS data (Figure S1) at $m / z 279.08790$ [M-H] ${ }^{-}$(calcd for $\mathrm{C}_{14} \mathrm{H}_{15} \mathrm{O}_{6}, 279.08741$ ), implying seven degrees of unsaturation. The ${ }^{1} \mathrm{H}$ NMR spectrum (Figure S2) (Table 1) along with the HSQC experiment showed three aromatic protons owing to a 1,2,3-trisubstituted aromatic ring $\left[\delta_{\mathrm{H}} 7.56(1 \mathrm{H}, \mathrm{t}, J=7.9 \mathrm{~Hz}) ; 6.96(1 \mathrm{H}, \mathrm{dd}, J=2.5,7.3 \mathrm{~Hz}) ; 6.96(1 \mathrm{H}, \mathrm{dd}, J=2.5,7.3 \mathrm{~Hz})\right]$, three methines $\left[\delta_{\mathrm{H}} 5.90(1 \mathrm{H}, \mathrm{t}, J=6.6 \mathrm{~Hz}) ; 4.86(1 \mathrm{H}, \mathrm{m}) ; 3.73(1 \mathrm{H}, \mathrm{m}) ;\right]$, one methylene $\left[\delta_{\mathrm{H}} 2.95(2 \mathrm{H}, \mathrm{m})\right]$, and two methyls $[1.25(3 \mathrm{H}, \mathrm{d}, J=6.4 \mathrm{~Hz}) ; 1.18(3 \mathrm{H}, \mathrm{d}, J=6.4 \mathrm{~Hz})]$. The ${ }^{13} \mathrm{C}$ NMR (Figure S3) and HSQC data (Figure S4) of $\mathbf{1}$ indicated the presence of 14 carbons for eight sp ${ }^{2}$ hybridized carbons including two ester carbonyls $\left(\delta_{C} 171.5,168.8\right)$ and six sp ${ }^{3}$ hybridized carbons $\left(\delta_{C} 78.3,76.3,70.1,39.7,19.1,16.4\right)$.

Table 1. ${ }^{1} \mathrm{H}(400 \mathrm{MHz})$ and ${ }^{13} \mathrm{C}(100 \mathrm{MHz}) \mathrm{NMR}$ data of $\mathbf{1}$ and $\mathbf{2}$ in $\mathrm{CDCl}_{3}$.

\begin{tabular}{|c|c|c|c|c|}
\hline \multirow{2}{*}{ No. } & \multicolumn{2}{|r|}{1} & \multicolumn{2}{|c|}{2} \\
\hline & $\delta_{\mathrm{C}}$, Type & $\delta_{\mathrm{H}},(J$ in $\mathrm{Hz})$ & $\delta_{\mathrm{C}}$, Type & $\delta_{\mathrm{H}},(J$ in $\mathrm{Hz})$ \\
\hline 1 & $171.5, \mathrm{C}$ & & $171.6, \mathrm{C}$ & \\
\hline 3 & $78.3, \mathrm{CH}$ & $5.90, \mathrm{t}(6.6)$ & $78.3, \mathrm{CH}$ & $5,87, \mathrm{t}(6.5)$ \\
\hline $3 a$ & $149.0, \mathrm{C}$ & & 149.0, C & \\
\hline 4 & $116.2, \mathrm{CH}$ & $6.96, \mathrm{dd}(2.5,7.3)$ & $116.2, \mathrm{CH}$ & 6.96, dd $(4.6,7.0)$ \\
\hline 5 & $137.4, \mathrm{CH}$ & $7.56, \mathrm{t}(7.9)$ & $137.4, \mathrm{CH}$ & $7.56, \mathrm{t}(7.8)$ \\
\hline 6 & $113.4, \mathrm{CH}$ & $6.96, \mathrm{dd}(2.5,7.3)$ & $113.5, \mathrm{CH}$ & 6.96, dd $(4.6,7.0)$ \\
\hline 7 & $156.7, \mathrm{C}$ & & $156.8, \mathrm{C}$ & \\
\hline $7 \mathrm{a}$ & $111.1, \mathrm{C}$ & & $111.1, \mathrm{C}$ & \\
\hline 8 & 39.7, $\mathrm{CH}_{2}$ & $2.95, \mathrm{~m}$ & 39.7, $\mathrm{CH}_{2}$ & $2.94, \mathrm{~m}$ \\
\hline 9 & $168.8, \mathrm{C}$ & & $168.9, \mathrm{C}$ & \\
\hline 10 & $76.3, \mathrm{CH}$ & $4.86, \mathrm{~m}$ & $76.2, \mathrm{CH}$ & $4.85, \mathrm{~m}$ \\
\hline 11 & $70.1, \mathrm{CH}$ & $3.73, \mathrm{~m}$ & $70.0, \mathrm{CH}$ & $3.75, \mathrm{~m}$ \\
\hline 12 & $19.1, \mathrm{CH}_{3}$ & $1.18, \mathrm{~d}(6.4)$ & $19.2, \mathrm{CH}_{3}$ & $1.19, \mathrm{~d}(6.3)$ \\
\hline 13 & $16.4, \mathrm{CH}_{3}$ & $1.25, \mathrm{~d}(6.4)$ & $16.3, \mathrm{CH}_{3}$ & $1.20, \mathrm{~d}(6.3)$ \\
\hline
\end{tabular}

A 7-hydroxybenzofuran was assigned by ${ }^{1} \mathrm{H}-{ }^{1} \mathrm{H}$ COSY correlations (Figure S5) between $\mathrm{H}-4$ and H-5, H-5 and H-6, H-6 and H-7, and HMBC correlations (Figure S6) from H-4 to C-3a and C-7a, and H-3 to ester carbonyl C-1, as well as four-bond W-type correlation from H-6 to ester carbonyl C-1 (Figure 2). The HMBC correlations from H-8 to C-3 and H-3 to C-9 indicated that C-8 of acetoxy was linked to C-3 of 7-hydroxy-benzofuran group. At the same time, ${ }^{1} \mathrm{H}_{-}{ }^{1} \mathrm{H}$ COSY correlations between $\mathrm{H}-12$ and $\mathrm{H}-10, \mathrm{H}-10$ and $\mathrm{H}-11, \mathrm{H}-11$, and HMBC correlations from a H-12 to C-10 and C-11, and H-13 to C-10 constructed a 2,3-butanediol group. The key HMBC correlations from H-10 to another ester carbonyl C-9 suggested that 2,3-butanediol group was connected to benzofuran moiety by ester bond. Finally, compound 1 was crystallized upon slow evaporation of chloroform solvent to give a crystal of the monoclinic space group $P 2$, which was detected by $X$-ray crystallography. The refinement of the $\mathrm{Cu} \mathrm{K} \alpha$ data resulted in a Flack parameter [18] of 0.04(17) and a Hooft parameter [19] of 0.07(5), which assigned the absolute configuration of $\mathbf{1}$ as $3 S, 10 S$, and $11 S$ (Figure 3). The absolute configuration of secondary alcohol was further resolved by a modified Mosher's method $[20,21]$. The chemical shifts for H-10, $\mathrm{H}-11, \mathrm{H}-12, \mathrm{H}-13$ of $\mathbf{1} \mathbf{a}$ and $\mathbf{1} \mathbf{b}$ were measured as $\delta_{\mathrm{H}} 5.19,5.32,1.20,1.17$ for $\mathbf{1} \mathbf{a}$, and $\delta_{\mathrm{H}} 5.18,5.31,1.31$, 1.07 for $\mathbf{1 b}$, respectively. The observed differences of chemical shifts $\left(\Delta \delta=\delta_{\mathrm{S}}-\delta_{\mathrm{R}}\right)$ (Figure 4) indicated that the $\mathrm{C}-11$ absolute configuration is $S$ in agreement with the $\mathrm{X}$-ray crystallography analysis. 


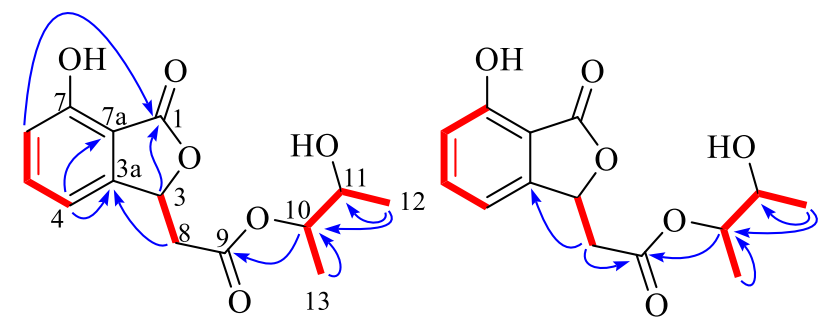

Figure 2. Key ${ }^{1} \mathrm{H}_{-}{ }^{1} \mathrm{H}$ COSY (red line) and HMBC (blue arrow) correlations of compounds $\mathbf{1}$ and 2.

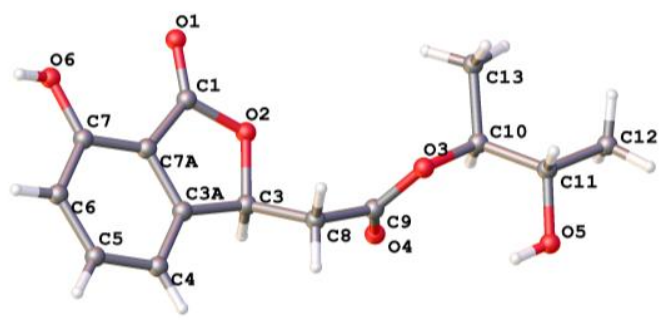

Figure 3. Single crystal structure of $\mathbf{1}$.<smiles>[R20][C@H](C)[C@@H](C)OC(=O)C[C@@H]1OC(=O)c2c(O)cccc21</smiles>

$1 \mathrm{R}=\mathrm{H}$

1a $\mathrm{R}=(S)$-MTPA ester

1b $\mathrm{R}=(R)-\mathrm{MTPA}$ ester<smiles>[R20][C@H](C)[C@@H](C)OC(=O)C[C@@H]1OC(=O)c2c(O)cccc21</smiles>

$2 \mathrm{R}=\mathrm{H}$

2a $\mathrm{R}=(S)$-MTPA ester

$\mathbf{2 b} \mathrm{R}=(R)$-MTPA ester

Figure 4. $\Delta \delta=\delta_{\mathrm{S}}-\delta_{\mathrm{R}}$ values in ppm obtained from the MTPA esters of $\mathbf{1}$ and 2.

Alternabenzofuran B (2) was isolated as a yellow oil and had the same molecular formula $\left(\mathrm{C}_{14} \mathrm{H}_{16} \mathrm{O}_{6}\right)$ as alternabenzofuran A (1) established by the HR-ESIMS ions at $m / z 279.08783$ [M-H] ${ }^{-}$ (calcd for $\mathrm{C}_{14} \mathrm{H}_{15} \mathrm{O}_{6}, 279.08741$ ) (Figure S11). Compound 2 shared the same planar structure as $\mathbf{1}$, and was further identified by $2 \mathrm{D}$ NMR spectra $\left({ }^{1} \mathrm{H}^{-1} \mathrm{H}\right.$ COSY, HSQC, and HMBC) (Figure S14-S16). The minor chemical shift variation of $\mathrm{C}-10\left(\delta_{\mathrm{C}} 76.3, \delta_{\mathrm{H}} 4.86\right.$ for $\mathbf{1} ; \delta_{\mathrm{C}} 76.4, \delta_{\mathrm{H}} 4.85$ for 2$), \mathrm{C}-11\left(\delta_{\mathrm{C}} 70.1\right.$, $\delta_{\mathrm{H}} 3.73$ for $1 ; \delta_{\mathrm{C}} 70.0, \delta_{\mathrm{H}} 3.75$ for 2$), \mathrm{C}-12\left(\delta_{\mathrm{C}} 19.1, \delta_{\mathrm{H}} 1.18\right.$ for $1 ; \delta_{\mathrm{C}} 19.2, \delta_{\mathrm{H}} 1.19$ for 2$)$ but obvious chemical shift variation of $\mathrm{C}-13\left(\delta_{\mathrm{C}} 16.4, \delta_{\mathrm{H}} 1.25\right.$ for $1 ; \delta_{\mathrm{C}} 16.3, \delta_{\mathrm{H}} 1.20$ for 2$)$ were observed, it suggested that 2 should be a 10-epimer of $\mathbf{1}$. At the same time, the absolute configuration of C-11 in $\mathbf{2}$, bearing a secondary hydroxyl group (11S), was also identified as same as that of $\mathbf{1}$ according to the modified Mosher's method. Therefore, compound $\mathbf{2}$ was identified as 10-epimer of $\mathbf{1}$, and named as alternabenzofuran B.

Alternaterpenoid A (3) was isolated as a white power and gave a molecular formula of $\mathrm{C}_{15} \mathrm{H}_{22} \mathrm{O}_{2}$ as determined from HR-ESIMS $\mathrm{m} / \mathrm{z} 235.16949[\mathrm{M}+\mathrm{H}]^{+}$(calcd for $\mathrm{C}_{15} \mathrm{H}_{23} \mathrm{O}_{2}, 235.16949$ ), implying 4 degrees of unsaturation (Figure S21). The ${ }^{1} \mathrm{H}$ NMR spectrum (Figure S22) (Table 2) showed one olefinic proton [ $\left.\delta_{\mathrm{H}} 5.53(1 \mathrm{H}, \mathrm{s})\right]$, one methine proton $\left[\delta_{\mathrm{H}} 1.97(1 \mathrm{H}, \mathrm{dd}, J=4.7,9.1 \mathrm{~Hz})\right]$, five methylene protons $\left[\delta_{\mathrm{H}} 1.39(1 \mathrm{H}, \mathrm{m}), 1.29(1 \mathrm{H}, \mathrm{m}) ; 1.54(1 \mathrm{H}, \mathrm{td}, J=1.6,3.3 \mathrm{~Hz}), 1.32(1 \mathrm{H}, \mathrm{td}, J=1.6,3.4 \mathrm{~Hz}) ; 1.83(1 \mathrm{H}, \mathrm{dt}\right.$, $J=3.5,13.6 \mathrm{~Hz}), 1.61(1 \mathrm{H}, \mathrm{t}, J=3.6 \mathrm{~Hz}) ; 1.69(1 \mathrm{H}, \mathrm{d}, J=4.1 \mathrm{~Hz}), 0.05(1 \mathrm{H}, \mathrm{t}, J=4.3 \mathrm{~Hz}) ; 3.22(1 \mathrm{H}, \mathrm{d}$, $J=11.3 \mathrm{~Hz}), 3.14(1 \mathrm{H}, \mathrm{d}, J=11.3 \mathrm{~Hz})]$ and three methyl protons $\left[\delta_{\mathrm{H}} 2.09(3 \mathrm{H}, \mathrm{s}) ; 1.18(3 \mathrm{H}, \mathrm{s}) ; 1.45(3 \mathrm{H}, \mathrm{s})\right]$. 
The ${ }^{13} \mathrm{C}$ NMR spectrum (Figure S23) displayed 15 carbons signals, including one conjugated carbonyl carbon $\left(\delta_{\mathrm{C}} 202.5\right)$, two double bond carbons $\left(\delta_{\mathrm{C}} 164.7\right.$ and 118.0$)$, and $12 \mathrm{sp}^{3}$ hybridized carbons.

Table 2. ${ }^{1} \mathrm{H}(400 \mathrm{MHz})$ and ${ }^{13} \mathrm{C}(100 \mathrm{MHz})$ NMR data of $\mathbf{1}$ and 2 in $\mathrm{CDCl}_{3}$.

\begin{tabular}{|c|c|c|c|c|}
\hline \multirow{2}{*}{ No. } & \multicolumn{2}{|c|}{3} & \multicolumn{2}{|c|}{4} \\
\hline & $\delta_{\mathrm{C}}$, Type & $\delta_{\mathrm{H}},(J$ in $\mathrm{Hz})$ & $\delta_{\mathrm{C}}$, Type & $\delta_{\mathrm{H}},(J$ in $\mathrm{Hz})$ \\
\hline \multirow{2}{*}{1} & \multirow{2}{*}{$34.1, \mathrm{CH}_{2}$} & $1.39, \mathrm{~m}$ & \multirow{2}{*}{$34.2, \mathrm{CH}_{2}$} & $1.77, \mathrm{~m}$ \\
\hline & & $1.29, \mathrm{~m}$ & & $1.45, \mathrm{~m}$ \\
\hline \multirow{2}{*}{2} & \multirow{2}{*}{$37.3, \mathrm{CH}_{2}$} & $1.54, \operatorname{td}(1.6,3.3)$ & \multirow{2}{*}{$40.0, \mathrm{CH}_{2}$} & $1.81, \mathrm{~m}$ \\
\hline & & $1.32, \operatorname{td}(1.6,3.4)$ & & $1.57, \mathrm{~m}$ \\
\hline \multirow{2}{*}{3} & \multirow{2}{*}{ 17.6, $\mathrm{CH}_{2}$} & $1.83, \mathrm{dt}(3.5,13.6)$ & \multirow{2}{*}{ 17.6, $\mathrm{CH}_{2}$} & $1.60, \mathrm{~m}$ \\
\hline & & $1.61, \mathrm{t}(3.6)$ & & $1.79, \mathrm{~m}$ \\
\hline 4 & $34.0, \mathrm{C}$ & & $51.0, \mathrm{C}$ & \\
\hline 5 & $36.7, \mathrm{C}$ & & $42.9, \mathrm{C}$ & \\
\hline 6 & $25.0, \mathrm{CH}$ & $1.97, \mathrm{dd}(4.7,9.1)$ & $39.3, \mathrm{CH}$ & $1.37, \mathrm{~m}$ \\
\hline 7 & $164.7, \mathrm{C}$ & & $164.6, \mathrm{C}$ & \\
\hline 8 & 118.0, $\mathrm{CH}$ & $5.53, \mathrm{~s}$ & 123.1, $\mathrm{CH}$ & $6.00, \mathrm{~s}$ \\
\hline 9 & 202.5, C & & $209.9, C$ & \\
\hline 10 & $46.8, \mathrm{C}$ & & $41.4, \mathrm{C}$ & \\
\hline 11 & \multirow{2}{*}{$24.6, \mathrm{CH}_{3}$} & \multirow{2}{*}{$2.09, \mathrm{~s}$} & \multirow{2}{*}{$71.3, \mathrm{CH}_{2}$} & $3.73, \mathrm{~d}(11.4)$ \\
\hline & & & & $3.32, \mathrm{~d}(11.4)$ \\
\hline 12 & 27.5, $\mathrm{CH}_{2}$ & $\begin{array}{l}1.69, \mathrm{~d}(4.1) \\
0.05, \mathrm{t}(4.3)\end{array}$ & $33.1, \mathrm{CH}_{2}$ & $\begin{array}{l}1.94, \mathrm{~m} \\
1.84, \mathrm{~m}\end{array}$ \\
\hline 13 & 22.6, $\mathrm{CH}_{3}$ & $1.18, \mathrm{~s}$ & $30.4, \mathrm{CH}_{3}$ & $1.16, \mathrm{~s}$ \\
\hline 14 & $72.1, \mathrm{CH}_{2}$ & $\begin{array}{l}3.22, \mathrm{~d}(11.3) \\
3.14 \mathrm{~d}(113)\end{array}$ & $27.0, \mathrm{CH}_{3}$ & $1.15, \mathrm{~s}$ \\
\hline 15 & $21.9, \mathrm{CH}_{3}$ & $1.45, \mathrm{~s}$ & $27.4, \mathrm{CH}_{3}$ & $1.34, \mathrm{~s}$ \\
\hline
\end{tabular}

The ${ }^{1} \mathrm{H}-{ }^{1} \mathrm{H}$ COSY correlations (Figure S25) between $\mathrm{H}-1$ and $\mathrm{H}-2, \mathrm{H}-2$ and $\mathrm{H}-3$, and the key HMBC correlations (Figure S26) from methyl protons $\mathrm{H}-15$ to C-1, C-5, and C-10, and H-13 to C-3, C-4, C-5, and C-14, established a cyclohexane moiety (A ring) attached with two methyl and hydroxymethyl at C-10 and C-4, respectively. Another cyclohexanone moiety (B ring) was assigned by the key HMBC correlations from methyl H-15 to carbonyl C-9, and two quandary carbons C-5 and C-10, another methyl H-11 to C-6, C-7, and C-8, and methylene protons H-12 to C-5 and C-6. The remaining three-member ring ( $\mathrm{C}$ ring) was identified by ${ }^{1} \mathrm{H}-{ }^{1} \mathrm{H}$ COSY correlations between $\mathrm{H}-6$ and $\mathrm{H}-12$, and key HMBC correlations from H-12 to C-4, C-5, C-6, C-7, and C-10. The planar structure with a 6/6/3 rings system was finally completed and belongs to the sesquiterpene thujopsene family [22]. The relative configuration of 3 was determined by the detailed analysis of NOESY data (Figure 5). NOE correlations of $\mathrm{H}-13$ with $\mathrm{H}-12$, and $\mathrm{H}-12$ with $\mathrm{H}-15$ suggested that the orientation of $\mathrm{H}-12, \mathrm{H}-13$, and $\mathrm{H}-15$ were on the same side and the relative configuration of 3 were $4 S^{*}, 5 S^{*}, 6 S^{*}, 10 R^{*}$. The theoretical ECD spectra were calculated by a quantum chemical method at the $[\mathrm{RB} 3 \mathrm{LYP} / 6311+\mathrm{G}(2 \mathrm{~d}, \mathrm{p})]$ level, and the predicted ECD curve of $(4 S, 5 S, 6 S, 10 R)-3$ was in good agreement with that of the experimental one (Figure 6). Therefore, the structure of 3 was established as $(4 S, 5 S, 6 S, 10 R)-3$ and named alternaterpenoid A. 


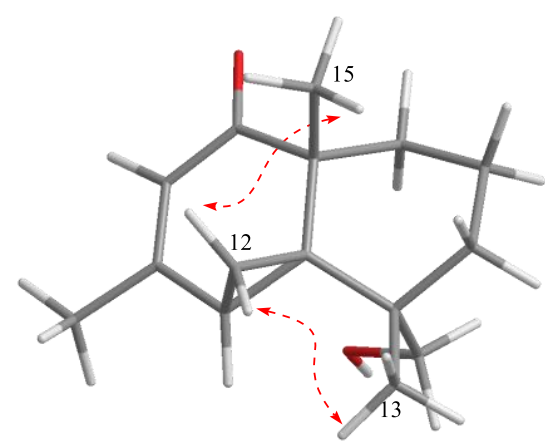

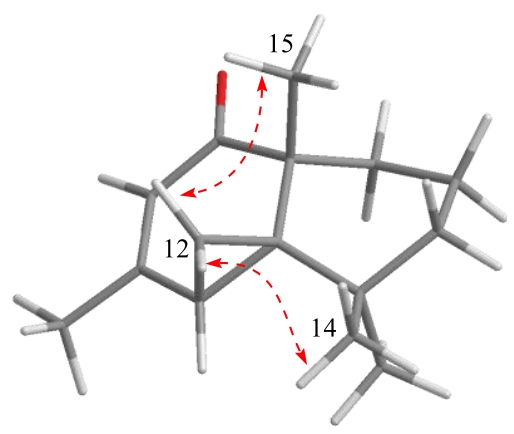

4

Figure 5. Key NOESY (dashed blue arrow) correlations of compounds 3 and 4 .
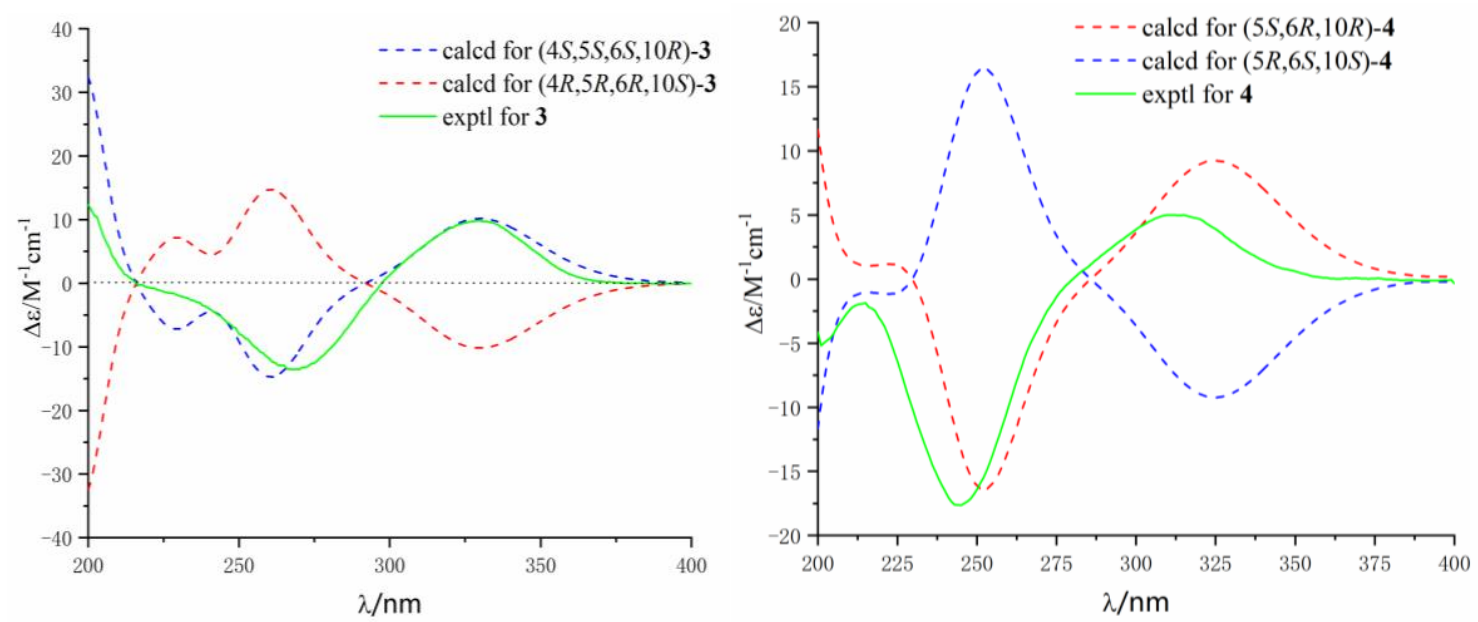

Figure 6. Experimental and calculated ECD spectra of compounds 3 and 4 (in $\mathrm{MeOH}$ ).

Alternaterpenoid B (4) was obtained as white power. According to HR-ESIMS m/z 235.1691 $[\mathrm{M}+\mathrm{H}]^{+}$(calcd for $\mathrm{C}_{15} \mathrm{H}_{23} \mathrm{O}_{2}, 235.1693$ ) analysis (Figure S29), compound 4 was found to have a molecular formula $\left(\mathrm{C}_{15} \mathrm{H}_{22} \mathrm{O}_{2}\right)$ as that of 3. The 1D NMR data (Figures S30 and S31) of 4 were closely comparable to those of 3, except for the change in the substitution group on C-11(71.3)/C-14(27.0), resulting in one hydroxymethyl on C-7(164.6) and C-4 (51.0) with methyl in 4. The deduction was further confirmed by the HMBC correlations (Figure S34) from the hydroxymethyl protons H-11 to C-6, C-7, and C-8, see Figure 7. The relative configuration of 4 was identified to be identical to 3 by interpretation of its NOESY spectrum (Figure 5 and Figure S35). The theoretical ECD spectra were calculated by a quantum chemical method at the [RB3LYP/6311+G(2d,p)] level, and the predicted ECD curve of $(5 S, 6 R, 10 R)-4$ was in good agreement with that of the experimental one (Figure 6). Therefore, the structure of 4 was established as $(5 S, 6 R, 10 R)-4$, and named alternaterpenoid B.

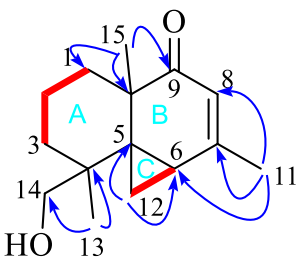

3

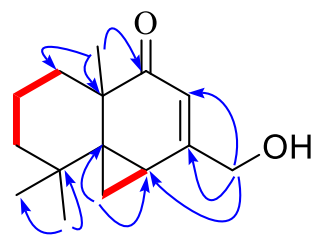

4

Figure 7. Key ${ }^{1} \mathrm{H}^{-1} \mathrm{H}$ COSY (red line) and HMBC (blue arrow) correlations of compounds 3 and 4. 
Additionally, 18 known compounds were identified as isobenzofuranone A (5) [23], isoochracinic acid (6) [24], (R)-1,6-dihydroxy-8-methoxy-3a-methyl-3,3a-dihydrocyclopenta[c]isochromene-2,5-dione (7) [25], dihydroaltenuenes A (8) [25], phialophriol (9) [25,26], \pm talaroflavone (10), alternariol-9-O-methyl ether (11) [27], alternariol (12) [27], 2-methyl-9-methoxy alternariol (13) [28], 3'-hydroxyalternariol 5-O-methyl ether (14) [29], alternariol-1'-hydroxy-9-methyl ether (15) [30], dehydroaltenusin (16) [31], alteryulactone (17) [31,32], tenuissimasatin (18) [33], 5'-methoxy-6-methyl-biphenyl-3,4,3'-triol (19) [29], altenusin (20) [34], 2,5-dimethyl-7-hydroxychromone (21) [35] and walterolactone C (22) [36] by comparing their spectroscopic data with published literature values.

In this work, all isolated compounds (1-22) were evaluated for their inhibition of nitric oxide (NO) production in RAW264.7 cells activated by lipopolysaccharide (LPS) using the Griess assay with indomethacin as a positive control (Table 3). Compounds 2, 3, 7, 9,10, 12-15, 17,18 and 20-22 showed stronger anti-inflammatory activity compared to the positive control indomethacin whose $\mathrm{IC}_{50}$ was $35.8 \pm 5.7 \mu \mathrm{M}$. Among them, compounds 3, 7, 9 and $\mathbf{1 4}$ displayed significant inhibitory effects on the production of $\mathrm{NO}$ with $\mathrm{IC}_{50}$ values below $10 \mu \mathrm{M}$, while compounds 5 and $\mathbf{1 1}$ exhibited moderate anti-inflammatory activity with $\mathrm{IC}_{50}$ values of 41.1 and $39.0 \mu \mathrm{M}$, respectively. To investigate whether the inhibitory activities of the active compounds were due to their cytotoxicity, the effects of the tested compounds on cell proliferation/viability were evaluated using the MTT method. Meanwhile, compounds $\mathbf{2}, \mathbf{9}, \mathbf{1 1}, \mathbf{1 4}$, and 17 (up to $100 \mu \mathrm{M}$ ) did not show any significant cytotoxicity with LPS treatment for $24 \mathrm{~h}$. The pro-inflammatory enzymes, inducible nitric oxide synthase (iNOS) for nitric oxide (NO) production and cyclooxygenase-2 (COX-2) for prostaglandin production, have been shown to play key roles in inflammatory processes. Therefore, further studies are required to clarify the underlying mechanism of the active compounds.

Table 3. Inhibitory activity of all compounds 1-22 against lipopolysaccharide (LPS)-induced NO production in the murine macrophage cell line (RAW 264.7 cells).

\begin{tabular}{cccc}
\hline Compounds & $\mathbf{I C}_{\mathbf{5 0}}(\boldsymbol{\mu M})$ & $\mathbf{C C}_{\mathbf{5 0}}(\mu \mathbf{M})^{\mathbf{a}}$ & $\mathbf{S I}^{\mathbf{b}}$ \\
\hline 1 & $>50$ & $>100$ & \\
$18.7 \pm 2.35$ & $>100$ & & \\
$2.4 \pm 0.79$ & $24.9 \pm 1.2$ & 10.4 & \\
4 & $\approx 50$ & $>100$ & \\
$41.1 \pm 4.78$ & $>100$ & & \\
$5.2 \pm 1.96$ & $20.6 \pm 2.3$ & 4.0 & \\
8 & $>50$ & $>100$ & \\
9 & $1.3 \pm 0.10$ & $>100$ & \\
10 & $23.9 \pm 3.30$ & $27.2 \pm 1.6$ & 1.1 \\
11 & $39.0 \pm 1.92$ & $>100$ & \\
12 & $16.6 \pm 1.60$ & $50.4 \pm 2.1$ & 3.0 \\
13 & $24.5 \pm 4.51$ & $48.2 \pm 2.6$ & 2.0 \\
14 & $5.9 \pm 0.48$ & $>100$ & \\
15 & $26.3 \pm 3.99$ & $48.7 \pm 1.8$ & 1.9 \\
17 & $16.2 \pm 2.62$ & $>100$ & \\
18 & $24.5 \pm 1.06$ & $28.3 \pm 2.5$ & 1.2 \\
$25.4 \pm 3.03$ & $>100$ & & \\
$14.9 \pm 1.92$ & $17.3 \pm 2.2$ & 1.2 & \\
22 & $14.9 \pm 1.92$ & $46.4 \pm 1.7$ & 3.1 \\
Indometacin & $35.8 \pm 5.7$ & & \\
\hline
\end{tabular}

a Values are taken as the means \pm standard deviation, $n=3{ }^{\mathrm{b}} \mathrm{SI}$, selectivity index, calculated by $\mathrm{CC}_{50} / \mathrm{IC}_{50}$;

${ }^{\mathrm{c}}$ Positive control.

In comparison of anti-inflammatory activity of two sesquiterpene thujopsene, 3 showed much stronger activity than that of 4 , indicating that the hydroxymethyl group (C-14) played an important role in anti-inflammatory action. For isocoumarins with 6/6/5 system (8 and 9 ), the keto carbonyl group at C-9 made no difference to the anti-inflammatory activity, while the hydroxyl group at 
C-9 made a more positive contribution to the anti-inflammatory activity. For another isocoumarins with 6/6/6 system (11-15), the substitution with the hydroxyl group at C-10 made a more positive contribution to the anti-inflammatory activity, while other substitution made no difference to the anti-inflammatory activity.

There has been a tremendous increase in pharmacological research on anti-inflammatory of marine-derived molecules, and more than 150 anti-inflammatory compounds derived from marine fungi have been reported past two decades [37,38]. The anti-inflammatory compounds are classified into different chemical classes, such as terpenes [39,40], steroids [41], polyketides [15], alkaloids [42], and peptides [43]. For example, tanzawaic acid Q (isolated from a marine-derived fungus, Penicillium steckii 108YD142) inhibited the lipopolysaccharide (LPS)-induced inducible nitric oxide synthase (iNOS) and cyclooxygenase-2 (COX-2) proteins and mRNA expressions in RAW 264.7 macrophages. Amestolkolides B (obtained from the mangrove endophytic fungus Talaromyces amestolkiae YX1) showed strong anti-inflammatory activity by inhibiting nitric oxide (NO) production in lipopolysaccharide activated in RAW264.7 cells with $\mathrm{IC}_{50}$ values of $1.6 \pm 0.1 \mathrm{Mm}$ in vitro [40]. A serial of mono- and dimeric sorbicillinoids (isolated from the marine-derived fungus Trichoderma reesei 4670) exhibited potent anti-inflammatory activity by inhibiting the production of NO in RAW264.7 cells activated by lipopolysaccharide with $\mathrm{IC}_{50}$ values in the range from 0.94 to $38 \mu \mathrm{M}$, whose structure-activity relationships were discussed [15]. Oxepinamide A (isolated from a marine-derived fungus Acremonium sp. from the surface of the Caribbean tunicate Ecteinascidia turbinata.) showed potent anti-inflammatory effect with the inhibition rate of $82 \%$ at the standard testing dose of $50 \mu \mathrm{g}$ per ear by a topical resiniferatoxin (RTX)-induced mouse ear edema assay [42]. Alternaramide (isolated from a marine Alternaria sp. SF-5016) showed the inhibition of the production of PGE2 and NO correlated with down-regulation of iNOS and COX-2 expression in LPS-induced RAW264.7 and BV2 macroglia cells with $\mathrm{IC}_{50}$ values ranging from 27.63 to $40.52 \mu \mathrm{M}$, and suppressed the NF- $\mathrm{B}$ and MAPK signaling pathway, as well as reduced the Toll-like receptor 4 (TLR4) and myeloid differentiation primary response gene 88 (MyD88) at the mRNA and protein levels [43]. Though there is no marine-derived anti-inflammatory agent currently on the market, the chemical diversity and biological activities of marine-derived molecules will provide medical and chemical researchers with a plenty variety of promising lead compounds for the development of anti-inflammatory marine drugs.

\section{Materials and Methods}

\subsection{General Experimental Procedures}

Optical rotations were measured on an MCP 200 polarimeter by using a Na lamp (Anton Paar). UV spectra were recorded using a Shimadzu UV-2501PC spectrometer (Shimadzu, Kyoto, Japan). To obtained ECD experiment data, Chirascan and Chirascan-Plus circular dichroism spectrometers (Applied Photophysics Ltd., Surrey, UK) were used. IR spectra were recorded using a Fourier transformation infra-red spectrometer coupled with infrared microscope EQUINOX 55 (Bruker, Rheinstetten, Germany). NMR spectra were obtained with a Bruker Avance 400 $\mathrm{MHz}$ spectrometer with tetramethylsilane as the internal standard (Bruker, Karlsruhe, Germany). HR-ESIMS data were determined by an LTQ-Orbitrap LC-MS spectrometer (Thermo Corporation, Waltham, MA, USA). ESIMS were acquired in an ACQUITY QDA (Waters Corporation, Milford, MA, USA). Silica gel 200-300 mesh (Qing dao Marine Chemical Factory, Qingdao, China) and Sephadex LH-20 (GF Healthcare, Littile Chalfont, UK) was used for column chromatography (CC). Semipreparative HPLC was performed on an Essentia LC-16 (Shimadzu, Shanghai, China). Thin layer chromatography was carried out on Pre-coated silica gel plates (Qingdao Huang Hai Chemical Group Co., G60, F-254, China). 


\subsection{Biological Material}

The fungal strain 5102 was isolated from an actiniae collected in the Laishizhou island $\left(22^{\circ} 27^{\prime} 49.7^{\prime \prime}\right.$ N 114 32' 21.4" E), Shenzhen City, Guangdong Province, China, in April 2016. The fungus was identified as Alternaria by an ITS sequence with $99 \%$ query coverage and $99 \%$ similarity to which has been deposited in GenBank under accession number EFJ809940.1. The fungal strain 5102 was deposited in GenBank with accession number MT742159.

\subsection{Extraction, Isolation, and Characterization}

The fungus was activated and purified on PDA plate, then implanted in a conical flask with PDB liquid (four $500 \mathrm{~mL}$ Erlenmeyer flasks; each containing $12 \mathrm{~g}$ of PDB powder and $15 \mathrm{~g}$ of artificial sea salt and $500 \mathrm{~mL}$ distilled $\mathrm{H}_{2} \mathrm{O}$ ) and cultured in a shaker chamber for three days ( $150 \mathrm{RPM}, 28^{\circ} \mathrm{C}$ ) to obtained seed liquid. The fungus's seed liquid cultured on a rice medium ( 150 bottles $500 \mathrm{~mL}$ conical flask; each bottle with $50 \mathrm{~g}$ of rice, $15 \mathrm{~g}$ of sea salt and $60 \mathrm{~mL}$ sterile water) with room temperature under daylight and stilling culture for one month. The fermented material was extracted with EtOAc three times and concentrated under reduced pressure. The EtOAc extract $(45.9 \mathrm{~g})$ was subjected to CC on silica gel (100-200 mesh) and was eluted with PE (petroleum ether)/EtOAc of increasing polarity (from 80:20 to 0:100) to afford seven fractions (A-F).

Fr. A was fractionated on a CC on silica gel (200-300 mesh) eluting with PE/EA (from 75:15 to 60:40) to afford 2 fractions (Fr.A.1, Fr.A.2). Fr.A.1 was further separated on Sephadex $\mathrm{LH}-20\left(\mathrm{CH}_{2} \mathrm{Cl}_{2} / \mathrm{MeOH}\right.$ $\mathrm{v} / \mathrm{v}, 1: 1$ ) and purified by NR-HPLC (n-hexane:IPA (isopropyl alcohol) v/v, 97:3, flow rate $1.5 \mathrm{~mL} / \mathrm{min}$, Ultimate $S$ column $10 \times 250 \mathrm{~mm}, 5 \mu \mathrm{m})$ to give $3(10.0 \mathrm{mg})$. Fr.A.2 was separated on Sephadex LH-20 $\left(\mathrm{CH}_{2} \mathrm{Cl}_{2} / \mathrm{MeOH} \mathrm{v} / \mathrm{v}, 1: 1\right)$ and further applied to a silica gel column eluting with PE/EA (from 75:15 to 60:40) to afford $\mathbf{8}(19.6 \mathrm{mg}), \mathbf{9}(18.0 \mathrm{mg})$ and $\mathbf{1 1}(46.0 \mathrm{mg})$, and others was purified by RP-HPLC with n-hexane/IPA (from 95:5 to 90:10) to give $\mathbf{7}(27 \mathrm{mg}), \mathbf{1 5}(17.3 \mathrm{mg}), \mathbf{1 7}(7.8 \mathrm{mg}), \mathbf{2 1}(9.4 \mathrm{mg})$ and $\mathbf{4}(3.0 \mathrm{mg})$. Fr. B was subjected to Sephadex LH-20 $\left(\mathrm{CH}_{2} \mathrm{Cl}_{2} / \mathrm{MeOH}\right.$ v/v, 1:1) to afford 6 fractions (Fr.B.1 to Fr.B.6). Fr.B.1 was fractionated on a CC on silica gel (200-300 mesh) eluting with PE/EA (from 80:20 to 70:30) to afford 3 fractions (Fr.B.1.1, Fr.B.1.2 and Fr.B.1.3). Fr.B.1.1 was further applied to a Sephadex LH-20 $\left(\mathrm{CH}_{2} \mathrm{Cl}_{2} / \mathrm{MeOH} \mathrm{v} / \mathrm{v}, 1: 1\right)$ to afford 22 (15.3 mg). Fr.B.1.2 was purified on silica gel column (PE/EA, 75:25) to obtain $5(16.4 \mathrm{mg})$ and $\mathbf{1 8}(10.3 \mathrm{mg})$. Fr.B.1.3 was separated on a CC on silica gel eluting with $\mathrm{CH}_{2} \mathrm{Cl}_{2} / \mathrm{MeOH}$ (from 97.5:2.5 to 96:4) to give $\mathbf{1 2}(6.4 \mathrm{mg}), \mathbf{1 3}(168 \mathrm{mg}), \mathbf{1 4}(23.5 \mathrm{mg}), \mathbf{1 6}(5 \mathrm{mg}), \mathbf{1 9}(4 \mathrm{mg})$ and $20(3.3 \mathrm{mg}$ ). Fr.B.2 was also purified on silica gel column with PE/EA (from 80:20 to 70:30) to obtain two fractions (Fr.B.2.1 and Fr.B.2.2). Fr.B.2.1 was successively applied to a silica gel with $\mathrm{CH}_{2} \mathrm{Cl}_{2} / \mathrm{MeOH}$ (97:3) to give 6 ( $4.4 \mathrm{mg}), 2-8 \mathrm{a} / 2-8 \mathrm{~b}(15.3 \mathrm{mg})$. Fr.B.2.2 was finally purified by NR-HPLC (n-hexane:IPA $\mathrm{v} / \mathrm{v}, 75: 25)$ to afford $\mathbf{2}(14.3 \mathrm{mg})$ and $\mathbf{1}(18.2 \mathrm{mg})$.

\subsubsection{Alternabenzofuran A (1)}

Colorless cluster crystals; $[\alpha]_{\mathrm{D}}^{25}-2.5$ (c 0.1, MeOH); UV (MeOH) $\lambda_{\max }(\log \varepsilon) 300$ (2.52), 235 (2.79), 206 (3.51) nm; IR (neat) $v_{\max }$ : 3444, 2968, 2923, 2857, 1743, 1609, 1471, 1384, 1317, 1286, 1265, 1181, 1087, 1009, 917, 865, 798, $690 \mathrm{~cm}^{-1}$ (Figure S8); ${ }^{1} \mathrm{H}$ NMR $\left(\mathrm{CDCl}_{3}, 400 \mathrm{MHz}\right)$ and ${ }^{13} \mathrm{C} \mathrm{NMR}\left(\mathrm{CDCl}_{3}, 100 \mathrm{MHz}\right)$ data, see Table 1; HR-ESIMS m/z $279.08790[\mathrm{M}-\mathrm{H}]^{-}$(calcd for $\mathrm{C}_{14} \mathrm{H}_{15} \mathrm{O}_{6}, 279.08741$ ).

\subsubsection{Alternabenzofuran B (2)}

Yellow oily; $[\alpha]_{\mathrm{D}}^{25}+3.3\left(\right.$ c 0.1, MeOH); UV (MeOH) $\lambda_{\max }(\log \varepsilon) 300$ (2.68), 237 (2.87), 206 (3.64) nm; IR (neat) $v_{\max }: 3439,2982,2928,1747,1609,1477,1382,1314-1280,1191,1078,1005,931,863,803$, $690 \mathrm{~cm}^{-1}$ (Figure S18); ${ }^{1} \mathrm{H} \mathrm{NMR}\left(\mathrm{CDCl}_{3}, 400 \mathrm{MHz}\right)$ and ${ }^{13} \mathrm{C} \mathrm{NMR}\left(\mathrm{CDCl}_{3}, 100 \mathrm{MHz}\right)$ data, see Table 1; HR-ESIMS m/z $279.08783[\mathrm{M}-\mathrm{H}]^{-}$(calcd for $\mathrm{C}_{14} \mathrm{H}_{15} \mathrm{O}_{6}, 279.08741$ ). 


\subsubsection{Alternaterpenoid A (3)}

White power; $[\alpha]_{\mathrm{D}}^{25}+1.7\left(\right.$ c 0.1, MeOH); UV (MeOH) $\lambda_{\max }(\log \varepsilon) 266$ (3.13), 230 (2.72) nm; $\mathrm{CD}(\mathrm{MeOH}) \lambda_{\max }(\Delta \varepsilon) 267(-13.5), 330(10.1) \mathrm{nm}$; IR (neat) $v_{\max }: 3430,2928,2864,1761,1723,1644,1438$, $1368,1260,1079,1034,872,798 \mathrm{~cm}^{-1}$ (Figure S28); ${ }^{1} \mathrm{H} \mathrm{NMR}\left(\mathrm{CDCl}_{3}, 400 \mathrm{MHz}\right)$ and ${ }^{13} \mathrm{C} \mathrm{NMR}\left(\mathrm{CDCl}_{3}\right.$, $100 \mathrm{MHz}$ ) data, see Table 2; HR-ESIMS $m / z 235.16949[\mathrm{M}+\mathrm{H}]^{+}\left(\right.$calcd for $\mathrm{C}_{15} \mathrm{H}_{23} \mathrm{O}_{2}, 235.16949$ ).

\subsubsection{Alternaterpenoid B (4)}

White power; $[\alpha]_{\mathrm{D}}^{25}-0.0\left(c\right.$ 0.1, MeOH); UV (MeOH) $\lambda_{\max }(\log \varepsilon) 244(2.67), 227$ (2.55) nm; $\mathrm{CD}(\mathrm{MeOH}) \lambda_{\max }(\Delta \varepsilon) 244$ (-17.6), 312 (5.0); IR (neat) $v_{\max }$ : 3440, 2923, 2864, 1674, 1457, 1373, 1243, 1177, 1094, 1049, 968, $848 \mathrm{~cm}^{-1}$ (Figure S36); ${ }^{1} \mathrm{H}$ NMR $\left(\mathrm{CDCl}_{3}, 400 \mathrm{MHz}\right)$ and ${ }^{13} \mathrm{C} \mathrm{NMR}\left(\mathrm{CDCl}_{3}, 100 \mathrm{MHz}\right)$ data, see Table 2; HR-ESIMS m/z 235.1691 [M + H] ${ }^{+}$(calcd for $\mathrm{C}_{15} \mathrm{H}_{23} \mathrm{O}_{2}$, 235.1693).

\subsection{X-ray Crystallographic Analysis of Compound 1}

Colorless crystals of compound 1 were obtained from a solvent of chloroform. Crystal data were acquired using the hemisphere technique on a Rigaku Oxford Diffraction diffractometer with graphite-monochromated $\mathrm{Cu}-\mathrm{K} \alpha$ (radiation $\lambda=1.54178 \AA$ ). The structure was solved by direct methods using SHELXS-97; refinement was done by full-matrix least-squares on F2 using the SHELXL-97 program suite on Olex2 Launcher.

Crystal data of (1): $\mathrm{C}_{14} \mathrm{H}_{15} \mathrm{O}_{6}, \mathrm{Mr}=280.27$, monoclinic, $a=9.69498(8) \AA, b=4.96003(5)$ $\AA, c=13.68007(10) \AA, \alpha=90^{\circ}, \beta=93.4053(7)^{\circ}, \gamma=90^{\circ}, V=656.677(10) \AA^{3}$, space group $P_{21}$, $T=150.0(4) \mathrm{K}, Z=2, D_{\text {calcd }}=1.417 \mathrm{~g} / \mathrm{cm}^{3}, \mu=0.942 \mathrm{~mm}^{-1}$, and $F(000)=296.0$. Crystal dimensions: $0.41 \times 0.14 \times 0.11 \mathrm{~mm}^{3}$. Independent reflections $2611\left(R_{\mathrm{int}}=0.0443\right)$, The goodness of fit on $\mathrm{F}^{2}$ was 1.075. The final $R_{1}$ values were $0.0331, w R_{2}=0.0910[I>2 \sigma(I)]$. The Flack parameter was $0.04(17)$ and the Hooft parameter was 0.07(5). CCDC number: 2010422.

\subsection{Preparation of (S)-MTPA Ester and (R)-MTPA Ester}

\subsection{1. (S)-MTPA Ester (1a) and (R)-MTPA Ester (1) $)$}

Compound $1(1.0 \mathrm{mg}, 10 \mu \mathrm{mol}),(R)-\mathrm{MPTACl}(10.0 \mu \mathrm{L}, 50 \mu \mathrm{mol})$, and pyridine- $d_{5}(0.5 \mathrm{~mL})$ were mixed in an NMR tube to a reaction (room temperature, $24 \mathrm{~h}$ ). Then the ${ }^{1} \mathrm{H}$ NMR data of the (S)-MTPA ester derivative (1a) was measured directly on the reaction mixture. ${ }^{1} \mathrm{H}$ NMR (Figure S9) (selected signals, pyridine- $\left.d_{5}, 400 \mathrm{MHz}\right) \delta_{\mathrm{H}}: 5.19(1 \mathrm{H}, \mathrm{m}, \mathrm{H}-10), 5.32(1 \mathrm{H}, \mathrm{m}, \mathrm{H}-11), 1.20(3 \mathrm{H}, \mathrm{d}, \mathrm{H}-12)$, $1.17(3 \mathrm{H}, \mathrm{d}, \mathrm{H}-13)$.

Similarly, another reaction of $1(1.0 \mathrm{mg}, 4 \mu \mathrm{mol}),(S)-\mathrm{MPTACl}(10.0 \mu \mathrm{L}, 52 \mu \mathrm{mol})$, and pyridine- $d_{5}$ $(0.5 \mathrm{~mL})$ was performed as described above for $\mathbf{1 a}$ to afford $\mathbf{1} \mathbf{b} .{ }^{1} \mathrm{H}$ NMR (Figure S10) (selected signals, pyridine- $\left.d_{5}, 400 \mathrm{MHz}\right) \delta_{\mathrm{H}}: 5.18(1 \mathrm{H}, \mathrm{m}, \mathrm{H}-10), 5.31(1 \mathrm{H}, \mathrm{m}, \mathrm{H}-11), 1.31(3 \mathrm{H}, \mathrm{d}, \mathrm{H}-12), 1.07(3 \mathrm{H}, \mathrm{d}, \mathrm{H}-13)$.

\subsection{2. (S)-MTPA Ester (2a) and (R)-MTPA Ester (2b)}

$(S)$-MTPA Ester (2a) and (R)-MTPA ester (2b) were easy to obtain refer to above method. ${ }^{1} \mathrm{H}$ NMR (Figures S19 and S20) (selected signals, pyridine- $\left.d_{5}, 400 \mathrm{MHz}\right) 2 \mathrm{a} \delta_{\mathrm{H}}: 5.19(1 \mathrm{H}, \mathrm{m}, \mathrm{H}-10)$, $5.35(1 \mathrm{H}, \mathrm{m}, \mathrm{H}-11), 1.17(3 \mathrm{H}, \mathrm{d}, \mathrm{H}-12), 1.17(3 \mathrm{H}, \mathrm{d}, \mathrm{H}-13) .2 \mathbf{b} \delta_{\mathrm{H}}: 5.18(1 \mathrm{H}, \mathrm{m}, \mathrm{H}-10), 5.33(1 \mathrm{H}, \mathrm{m}, \mathrm{H}-11)$, $1.29(3 \mathrm{H}, \mathrm{d}, \mathrm{H}-12), 1.09$ (3H, d, H-13).

\subsection{Calculation of the ECD Spectra}

Molecular Merck force field (MMFF) and DFT/TD-DFT calculations were carried out with Spartan' 14 software (Wavefunction Inc., Irvine, CA, USA) and Gaussian 09 program, respectively. Conformers within $10 \mathrm{kcal} / \mathrm{mol}$ energy window were obtained and optimized by DFT calculations at B3LYP/6-31G(d) level. Conformers with Bolzmann distribution over 1\% were selected for ECD calculations in methanol at B3LYP/6-311+g(2d,p) level (Figures S67 and S68). The IEF-PCM solvent 
model for $\mathrm{MeOH}$ was used. ECD spectra were generated using the program SpecDis 3.0 (University of Würzburg, Würzburg, Germany) and OriginPro 8.5 (OriginLab, Ltd., Northampton, MA, USA) from dipole-length rotational strengths by applying Gaussian band shapes with sigma $=0.30 \mathrm{ev}$. All calculations were performed by Tianhe- 2 in the National Super Computer Center in Guangzhou.

\subsection{Cell Viability Assay and Anti-Inflammatory Activity}

Cell viability was measured using the conventional MTT assay. RAW 264.7 cells were seeded in 96-well plates at a density of $1.5 \times 10^{5}$ cells $/ \mathrm{mL}$. After $12 \mathrm{~h}$, the cells were treated with LPS $(1 \mu \mathrm{g} / \mathrm{mL})$ and samples, followed by additional incubation for $24 \mathrm{~h}$ at $37^{\circ} \mathrm{C}$. MTT stock solution $(2 \mathrm{mg} / \mathrm{mL})$ was added to wells for a total reaction volume of $110 \mu \mathrm{L}$. After $4 \mathrm{~h}$ incubation, the supernatants were aspirated. The formazan crystals in each well were dissolved in $50 \mu \mathrm{L}$ of DMSO, and the absorbance was measured using a microplate reader (Multiskan GO, Thermo Scientific, Waltham, MA, USA) at the wavelength of $490 \mathrm{~nm}$. Relative cell viability was evaluated based on the quantity of MTT converted to the insoluble formazan salt. The optical density of formazan generated in the control cells represented $100 \%$ viability. The data were expressed as mean percentages of the viable cells compared to the respective control.

After pre-incubation of RAW 264.7 cells $\left(1.5 \times 10^{5}\right.$ cells $\left./ \mathrm{mL}\right)$ with LPS $(1 \mu \mathrm{g} / \mathrm{mL})$ and samples at $37^{\circ} \mathrm{C}$ for $24 \mathrm{~h}$, the quantity of nitrite accumulated in the culture medium was measured as an indicator of NO production. Briefly, $50 \mu \mathrm{L}$ of cell culture medium were mixed with $100 \mu \mathrm{L}$ Griess reagent, and incubated at room temperature for $10 \mathrm{~min}$. The absorbance was determined at $540 \mathrm{~nm}$ wavelength with a microplate reader (Multiskan GO, Thermo Scientific, Waltham, MA, USA).

\subsection{Statistical Analysis}

Each experiment was performed at least three times independently, and the resulting data are presented as the mean \pm standard deviation. The comparison of three or more groups used one-way analysis of variance, followed by Tukey's multiple comparison tests. Statistical analysis was performed using GraphPad Prism software, version 3.03 (GraphPad Software Inc, GraphPad Software Inc., San Diego, CA, USA).

\section{Conclusions}

The fungal genus Alternaria are a significant source of pharmacologically active metabolites with interesting structural properties. Chemical investigation of an extract of marine-derived fungus Alternaria sp. 5102 from rice medium led to the discovery of two new benzofurans, alternabenzofurans $A$ and $B$ (1 and 2 ) and two new sesquiterpenoids, alternaterpenoids $A$ and $B$ ( 3 and 4 ), along with 18 known polyketides (5-22). Their structures were clearly elucidated by extensive spectroscopic analyses and X-ray crystallography, as well as the modified Mosher's method. Most of isolated molecules $(\mathbf{2}, \mathbf{3}, \mathbf{5}, \mathbf{7}, \mathbf{9 - 1 8}$, and 20-22) exhibited potent anti-inflammatory activity by inhibiting the production of NO in RAW264.7 cells activated by lipopolysaccharide with $\mathrm{IC}_{50}$ values in the range from 1.3 to $41.1 \mu \mathrm{M}$.

Supplementary Materials: The following are available online at http://www.mdpi.com/1660-3397/18/8/426/s1, HR-ESIMS, NMR of the new compounds as well as other supporting data.

Author Contributions: S.C. and H.L. conceived and designed the experiments; Y.D. and S.C. performed the experiments; C.Y., Z.W., H.G. and L.L. participated into the experimental process and result discussion. S.C. and H.L. analyzed the data and wrote the paper. All authors have read and agreed to the published version of the manuscript.

Funding: This work was financially supported by the National Natural Science Foundation of China (Grant No. 41906033, 41806155), Special Fund for Promoting High-Quality Economic Development in Guangdong Province (Marine Economic Development Project) (Grant No. GDOE-2019A21), the Natural Science Foundation of Guangdong Province of China (grant number 2019A1515012084,2018A030310304).

Conflicts of Interest: The authors declare no conflict of interest. 


\section{References}

1. Carroll, A.R.; Copp, B.R.; Davis, R.A.; Keyzers, R.A.; Prinsep, M.R. Marine natural products. Nat. Prod. Rep. 2019, 36, 122-173. [CrossRef] [PubMed]

2. Blunt, J.W.; Carroll, A.R.; Copp, B.R.; Davis, R.A.; Keyzers, R.A.; Prinsep, M.R. Marine natural products. Nat. Prod. Rep. 2018, 35, 8-53. [CrossRef] [PubMed]

3. Jiang, M.; Wu, Z.; Guo, H.; Liu, L.; Chen, S. A review of terpenes from marine-derived fungi: 2015-2019. Mar. Drugs 2020, 18, 321. [CrossRef] [PubMed]

4. Jiang, M.; Chen, S.; Li, J.; Liu, L. The biological and chemical diversity of tetramic acid compounds from marine-derived microorganisms. Mar. Drugs 2020, 18, 114. [CrossRef]

5. Ding, H.; Zhang, D.; Zhou, B.; Ma, Z. Inhibitors of BRD4 protein from a marine-derived fungus Alternaria sp. NH-F6. Mar. Drugs 2017, 15, 76. [CrossRef]

6. Chen, Y.; Mao, W.-J.; Yan, M.-X.; Liu, X.; Wang, S.-Y.; Xia, Z.; Xiao, B.; Cao, S.-J.; Yang, B.-Q.; Li, J. Purification, chemical characterization, and bioactivity of an extracellular polysaccharide produced by the marine sponge endogenous fungus Alternaria sp. SP-32. Mar. Biotech. 2016, 18, 301-313. [CrossRef]

7. Shi, Z.-Z.; Miao, F.-P.; Fang, S.-T.; Liu, X.-H.; Yin, X.-L.; Ji, N.-Y. Sesteralterin and Tricycloalterfurenes A-D: Terpenes with Rarely Occurring Frameworks from the Marine-Alga-Epiphytic Fungus Alternaria alternata k21-1. J. Nat. Prod. 2017, 80, 2524-2529. [CrossRef]

8. Huang, C.-H.; Pan, J.-H.; Chen, B.; Yu, M.; Huang, H.-B.; Zhu, X.; Lu, Y.-J.; She, Z.-G.; Lin, Y.-C. Three bianthraquinone derivatives from the mangrove endophytic fungus Alternaria sp. ZJ9-6B from the South China Sea. Mar. Drugs 2011, 9, 832-843. [CrossRef]

9. Zheng, C.-J.; Shao, C.-L.; Guo, Z.-Y.; Chen, J.-F.; Deng, D.-S.; Yang, K.-L.; Chen, Y.-Y.; Fu, X.-M.; She, Z.-G.; Lin, Y.-C. Bioactive hydroanthraquinones and anthraquinone dimers from a soft coral-derived Alternaria sp. fungus. J. Nat. Prod. 2012, 75, 189-197. [CrossRef]

10. Lou, J.; Fu, L.; Peng, Y.; Zhou, L. Metabolites from Alternaria fungi and their bioactivities. Molecules 2013, 18, 5891-5935. [CrossRef]

11. Shaaban, M.; Shaaban, K.A.; Abdel-Aziz, M.S. Seven naphtho- $\gamma$-pyrones from the marine-derived fungus Alternaria alternata: Structure elucidation and biological properties. Org. Med. Chem. Lett. 2012, 2, 6. [CrossRef] [PubMed]

12. Pan, D.; Zhang, X.; Zheng, H.; Zheng, Z.; Nong, X.; Liang, X.; Ma, X.; Qi, S. Novel anthraquinone derivatives as inhibitors of protein tyrosine phosphatases and indoleamine 2,3-dioxygenase 1 from the deep-sea derived fungus Alternaria tenuissima DFFSCS013. Org. Chem. Front. 2019, 6, 3252-3258. [CrossRef]

13. Wang, H.-L.; Li, R.; Li, J.; He, J.; Cao, Z.-Y.; Kurtaán, T.; Mándi, A.; Zheng, G.-L.; Zhang, W. Alternarin A, a Drimane Meroterpenoid, Suppresses Neuronal Excitability from the Coral-Associated Fungi Alternaria sp. ZH-15. Org. Lett. 2020, 22, 2995-2998. [CrossRef] [PubMed]

14. Chen, S.; Liu, Z.; Liu, H.; Long, Y.; Chen, D.; Lu, Y.; She, Z. Lasiodiplactone A, a novel lactone from the mangrove endophytic fungus Lasiodiplodia theobromae ZJ-HQ1. Org. Biomol. Chem. 2017, 15, 6338-6341. [CrossRef] [PubMed]

15. Zhang, P.; Deng, Y.; Lin, X.; Chen, B.; Li, J.; Liu, H.; Chen, S.; Liu, L. Anti-inflammatory mono- and dimeric sorbicillinoids from the marine-derived fungus Trichoderma reesei 4670. J. Nat. Prod. 2019, 82, 947-957. [CrossRef]

16. Chen, S.; Jiang, M.; Chen, B.; Salaenoi, J.; Niaz, S.-I.; He, J.; Liu, L. Penicamide A, a unique N, N'-ketal quinazolinone alkaloid from ascidian-derived fungus Penicillium sp. 4829. Mar. Drugs 2019, 17, 522. [CrossRef]

17. Shen, H.; Liu, X.; Jiang, M.; Luo, G.; Wu, Z.; Chen, B.; Li, J.; Liu, L.; Chen, S. Anti-Inflammatory Cembrane-Type Diterpenoids and Prostaglandins from Soft Coral Lobophytum sarcophytoides. Mar. Drugs 2019, $17,481$. [CrossRef]

18. Flack, H.D.; Bernardinelli, G. The use of X-ray crystallography to determine absolute configuration. Chirality 2008, 20, 681-690. [CrossRef]

19. Hooft, R.W.; Straver, L.H.; Spek, A.L. Determination of absolute structure using Bayesian statistics on Bijvoet differences. J. Appl. Crystal. 2008, 41, 96-103. [CrossRef]

20. Ohtani, I.; Kusumi, T.; Kashman, Y.; Kakisawa, H. High-field FT NMR application of Mosher's method. The absolute configurations of marine terpenoids. J. Am. Chem. Soc. 1991, 113, 4092-4096. [CrossRef] 
21. Zhang, P.; Li, Y.; Jia, C.; Lang, J.; Niaz, S.-I.; Li, J.; Yuan, J.; Yu, J.; Chen, S.; Liu, L. Antiviral and anti-inflammatory meroterpenoids: Stachybonoids A-F from the crinoid-derived fungus Stachybotrys chartarum 952. RSC Adv. 2017, 7, 49910-49916. [CrossRef]

22. Hong, Y.J.; Tantillo, D.J. Branching out from the bisabolyl cation. Unifying mechanistic pathways to barbatene, bazzanene, chamigrene, chamipinene, cumacrene, cuprenene, dunniene, isobazzanene, iso- $\gamma$-bisabolene, isochamigrene, laurene, microbiotene, sesquithujene, sesquisabinene, thujopsene, trichodiene, and widdradiene sesquiterpenes. J. Am. Chem. Soc. 2014, 136, 2450-2463. [PubMed]

23. Wang, Y.; Liu, H.-X.; Chen, Y.-C.; Sun, Z.-H.; Li, H.-H.; Li, S.-N.; Yan, M.-L.; Zhang, W.-M. Two new metabolites from the endophytic fungus Alternaria sp. A744 derived from Morinda officinalis. Molecules 2017, 22, 765. [CrossRef] [PubMed]

24. Choi, P.J.; Sperry, J.; Brimble, M.A. Heteroatom-directed reverse Wacker oxidations. Synthesis of the reported structure of (-)-herbaric acid. J. Org. Chem. 2010, 75, 7388-7392. [CrossRef] [PubMed]

25. Liu, Y.; Wu, Y.; Zhai, R.; Liu, Z.; Huang, X.; She, Z. Altenusin derivatives from mangrove endophytic fungus Alternaria sp. SK6YW3L. RSC Adv. 2016, 6, 72127-72132. [CrossRef]

26. Ye, F.; Chen, G.-D.; He, J.-W.; Li, X.-X.; Sun, X.; Guo, L.-D.; Li, Y.; Gao, H. Xinshengin, the first altenusin with tetracyclic skeleton core from Phialophora spp. Tetrahedron Lett. 2013, 54, 4551-4554. [CrossRef]

27. Hildebrand, A.A.; Kohn, B.N.; Pfeiffer, E.; Wefers, D.; Metzler, M.; Bunzel, M. Conjugation of the mycotoxins alternariol and alternariol monomethyl ether in tobacco suspension cells. J. Agri. Food Chem. 2015, 63, 4728-4736. [CrossRef]

28. Sun, J.; Awakawa, T.; Noguchi, H.; Abe, I. Induced production of mycotoxins in an endophytic fungus from the medicinal plant Datura stramonium L.. Bioorg. Med. Chem. Lett. 2012, 22, 6397-6400. [CrossRef]

29. He, J.-W.; Chen, G.-D.; Gao, H.; Yang, F.; Li, X.-X.; Peng, T.; Guo, L.-D.; Yao, X.-S. Heptaketides with antiviral activity from three endolichenic fungal strains Nigrospora sp., Alternaria sp. and Phialophora sp. Fitoterapia 2012, 83, 1087-1091. [CrossRef]

30. Zhang, J.-c.; Chen, G.-Y.; Li, X.-Z.; Hu, M.; Wang, B.-Y.; Ruan, B.-H.; Zhou, H.; Zhao, L.-X.; Zhou, J.; Ding, Z.-T. Phytotoxic, antibacterial, and antioxidant activities of mycotoxins and other metabolites from Trichoderma sp. Nat. Prod. Res. 2017, 31, 2745-2752. [CrossRef]

31. Shi, Y.-N.; Pusch, S.; Shi, Y.-M.; Richter, C.; Macia-Vicente, J.G.; Schwalbe, H.; Kaiser, M.; Opatz, T.; Bode, H.B. $( \pm)$-Alternarlactones A and B, Two Antiparasitic Alternariol-like Dimers from the Fungus Alternaria alternata P1210 Isolated from the Halophyte Salicornia sp. J. Org. Chem. 2019, 84, 11203-11209. [CrossRef] [PubMed]

32. Agrawal, S.; Deshmukh, S.K.; Reddy, M.S.; Prasad, R.; Goel, M. Endolichenic fungi: A hidden source of bioactive metabolites. S. Afr. J. Bot. 2020. [CrossRef]

33. Wang, Q.-X.; Bao, L.; Yang, X.-L.; Guo, H.; Yang, R.-N.; Ren, B.; Zhang, L.-X.; Dai, H.-Q.; Guo, L.-D.; Liu, H.-W. Polyketides with antimicrobial activity from the solid culture of an endolichenic fungus Ulocladium sp. Fitoterapia 2012, 83, 209-214. [CrossRef] [PubMed]

34. Pang, X.; Lin, X.; Wang, P.; Zhou, X.; Yang, B.; Wang, J.; Liu, Y. Perylenequione derivatives with anticancer activities isolated from the marine sponge-derived fungus, Alternaria sp. SCSIO41014. Mar. Drugs 2018, 16, 280. [CrossRef] [PubMed]

35. Qiu, D.; Zhou, M.; Lin, T.; Chen, J.; Wang, G.; Huang, Y.; Jiang, X.; Tian, W.; Chen, H. Cytotoxic Components from Hypericum elodeoides Targeting $\mathrm{RXR} \alpha$ and Inducing HeLa Cell Apoptosis through Caspase-8 Activation and PARP Cleavage. J. Nat. Prod. 2019, 82, 1072-1080. [CrossRef] [PubMed]

36. Kim, K.H.; Shin, Y.J.; Choi, S.U.; Lee, K.R. New cytotoxic $\delta$-valerolactones from Cornus walteri. Bull. Korean Chem. Soc. 2011, 32, 2443-2445. [CrossRef]

37. Cheung, R.C.F.; Ng, T.B.; Wong, J.H.; Chen, Y.; Chan, W.Y. Marine natural products with anti-inflammatory activity. Appl. Microbiol. Biol. 2016, 100, 1645-1666. [CrossRef]

38. Xu, J.; Yi, M.; Ding, L.; He, S. A Review of Anti-Inflammatory Compounds from Marine Fungi, 2000-2018. Mar. Drugs 2019, 17, 636. [CrossRef]

39. Niu, S.; Xie, C.; Xia, J.; Luo, Z.; Shao, Z.; Yang, X. New anti-inflammatory guaianes from the Atlantic hydrotherm-derived fungus Graphostroma sp. MCCC 3A00421. Sci. Rep. 2018, 8, 530. [CrossRef]

40. Chen, S.; Ding, M.; Liu, W.; Huang, X.; Liu, Z.; Lu, Y.; Liu, H.; She, Z. Anti-inflammatory meroterpenoids from the mangrove endophytic fungus Talaromyces amestolkiae YX1. Phytochemistry 2018, 146, 8-15. [CrossRef] 
41. Liu, M.; Sun, W.; Wang, J.; He, Y.; Zhang, J.; Li, F.; Qi, C.; Zhu, H.; Xue, Y.; Hu, Z.; et al. Bioactive secondary metabolites from the marine-associated fungus Aspergillus terreus. Bioorg. Chem. 2018, 80, 525-530. [CrossRef] [PubMed]

42. Belofsky, G.N.; Anguera, M.; Jensen, P.R.; Fenical, W.; Kock, M. Oxepinamides A-C and Fumiquinazolines H-I: Bioactive metabolites from a marine isolate of a fungus of the genus Acremonium. Chem. A Eur. J. 2000, 6, 1355-1360. [CrossRef]

43. Ko, W.; Sohn, J.H.; Jang, J.H.; Ahn, J.S.; Kang, D.G.; Lee, H.S.; Kim, J.S.; Kim, Y.C.; Oh, H. Inhibitory effects of alternaramide on inflammatory mediator expression through TLR4-MyD88-mediated inhibition of NF-кB and MAPK pathway signaling in lipopolysaccharide-stimulated RAW264.7 and BV2 cells. Chem. Biol. Interact. 2016, 244, 16-26. [CrossRef]

(C) 2020 by the authors. Licensee MDPI, Basel, Switzerland. This article is an open access article distributed under the terms and conditions of the Creative Commons Attribution (CC BY) license (http://creativecommons.org/licenses/by/4.0/). 